THE ROYALIST REVOLUTION 



\section{THE ROYALIST REVOLUTION}

MONARGH Y A D T H E

A M E R A A N F U N D N G

ERIC NELSON

The Belknap Press of Harvard University Press

Cambridge, Massachusetts

London, England

2014 
Copyright (C) 2014 by the President and Fellows of Harvard College ALL RIGHTS RESERVED

Printed in the United States of America

First printing

Library of Congress Cataloging-in-Publication Data

Nelson, Eric, 1977-

The royalist revolution : monarchy and the American founding / Eric Nelson.

pages $\mathrm{cm}$.

Includes bibliographical references and index.

ISBN 978-0-674-73534-7 (alk. paper)

I. Political science-United States-History-I8th century. 2. United States-Politics and government-I8th century. 3. Constitutional history-United States—I8th century.

4. Monarchy. I. Title.

JA84.U5N35 2014

320.47309'033-dc23 2014008415 
For Quentin Skinner,

friend and teacher 
